\title{
Migration Movements and Their Implications for Republic of Macedonia
}

\author{
Marina Andeva (Corresponding author) \\ School of Political Science, University American College Skopje \\ Treta Makedonska Brigada, 60, 1000 Skopje \\ Tel: 0038975338383 E-mail: marina.andeva@uacs.edu.mk
}

Received: March 11, 2017 Accepted: April 14, 2017 Published: August 10, 2017

doi:10.5296/ijssr.v5i2.10918ＵRL: http://dx.doi.org/10.5296/ijssr.v5i2.10918

\begin{abstract}
Migrants and refugees greatly challenged European leaders and policymakers. Mediterranean external borders of the European Union have been largely affected with tragic events and overwhelming management of huge migration flows, which in the last two to three years have changed their course through the territory of Western Balkan countries. In times when unfortunately, an establishment of a single unified system based on the principle of shared-burden and solidarity waits for practical implementation and execution, a part of the shared-burden and responsibility for managing migration flows have been transferred to the transit countries along the so-called "Balkan route". The Republic of Macedonia and its role within the Balkan route has been seen crucial and frequently disputed. Understanding the position of this country, requires an overview of few aspects which need to be taken into account. In order to assist this endeavor, this article will attempt to presents the Macedonia experiences with migration movements. The article discusses upon two main aspects of migration: 1) free movements of persons; and 2) accepting and treating of refugees. Furthermore, the article presents the main aspects of the Macedonian legal framework in the field of migration and asylum. As conclusion, it is evident that the county was challenged on several levels and fields. At first in seeking to prevent asylum applications from its citizens submitted in the EU countries; and secondly, in dealing with large influx of migrants with additional legal measures and remedies, not aligned competently with the EU acquis communitaire in the field of migration and asylum. And finally, Macedonian society in a period of migration and humanitarian crisis was both humanitarian in all aspects (assisting and helping refugees), however also nurtured prejudices towards refugees passing through Macedonian territory.
\end{abstract}

Keywords: asylum, compliance, EU, Macedonia, migration 


\section{Introduction}

Migrants and refugees coming from Africa, the Middle East, and South Asia have presented European leaders and policymakers with their greatest challenge since the Europe's economic crisis. Mediterranean external borders of the European Union have been largely affected with tragic events and overwhelming management of huge migration flows, which in the last two to three years have changed their course through the territory of Western Balkan countries. In times when unfortunately, an establishment of a single unified system based on the principle of shared-burden and solidarity is still waiting for practical implementation and execution, a part of the shared-burden and responsibility for managing migration flows have been transferred to the transit countries along the so-called "Balkan route". The Republic of Macedonia and its role within the Balkan route has been seen crucial and frequently disputed. Understanding the position of this country, requires an overview of few aspects which need to be taken into account. In order to assist this endeavor, this chapter will attempt to presents the Macedonia experiences with migration movements.

Human migration comprises different events and actions, each distinctly characterized depending on different factors and features. Migration is characterized by movements by people from one place to another followed by different reasons and intentions. Migration can be voluntary or forced; internal or external; it can be for economic or family reasons, or worst in can be triggered by wars and terror. Migration is also distinguished on whether a person exists from one state with an intention to settle to another (emigration) or as a process by which non-nationals move into a country for the purpose of settlement (IOM, 2011).

In view of the general consideration of what can constitute migration and migration movements, in the attempt to illustrate Macedonia's position and challenges, the narrative will be presented in three different areas. At first this chapter focuses on the right of free movement of persons and Macedonia position and the recent emigration issues. Subsequent, the discussion, on the effects of the current migration crises for Macedonia as one of the transit countries on the Balkan route, will change the narrative towards Macedonia's position as transit and destination country. At last, this chapter presents in brief the Macedonian legal framework in the field of illegal migration and asylum and argues on whether and to what extent the country's regulatory framework is in compliance with the EU measures in the specific areas.

\section{The Right of Free Movement of Persons in Macedonia}

\subsection{Reasons Behind the Need to Discuss Free Movement of Persons}

With an effect from 19 December 2009, citizens of the Republic of Macedonia were allowed to travel to Europe without having to apply for visas at consular offices of EU Member-States in their country or in the neighbouring countries (Council of the European Union, 2009). Visa liberalization towards the Western Balkans has been accompanied by concern among the member states of the EU that citizens of these countries are "abusing" the liberalization and free entry to the EU for a period of time for a particular activity or for reasons that were not provided for under national and European legislation. Member States of the EU registering 
significant increase in asylum applications in 2011 have intensified calls to the governments of the Western Balkan countries on issues related to the proper management of their migration outflows and a number of bilateral and regional meetings were held regarding the matter. Pressure on countries in the region became even higher in May 2011 when the European Commission proposed a temporary suspension of visa liberalization for Serbia, Macedonia, Bosnia and Herzegovina, Albania and Montenegro. Under the proposal, the suspension would be possible if a group of Member States of the EU show an increase of asylum seekers from these countries above a certain threshold (Council of Europe, 2013). On 12 September 2013, the European Parliament adopted a mechanism for the suspension of the visa regime, which allows the EU to restore visa in emergencies (European Parliament, 2013). Various calls were made by the representatives of the EU to the authorities of those countries pointing out that it is essential to take all necessary measures to reduce asylum seekers, stressing that if the problem persists, the visa liberalization process will be jeopardized and visas will be reinstated. After registered alarming figures for the Member States, the European Union has shifted the responsibility on the governments of the Western Balkans to address the issue of asylum seekers.

In her speech, Viviane Reding, Vice President of the European Commission, indicated that Roma were the real problem for the free movement in the EU (Romea, 2014). She stressed that all 507 million EU citizens have equal rights and added that, in the several decades of the Union's existence, there has never been such intense attacks from politicians and media against one of the main European rights - the right to freedom of movement. In a different speech she specifically pointed out that "free movement is a right to free circulation; it is not a right to migrate in Member States' social security systems" (European Commission, 2014). The last fourth report of the European Commission, which concerns the monitoring of visa liberalization for the Western Balkan countries, noted that in 2013, according to an annual analysis of Frontex, the majority of asylum seekers are Roma. In Germany, more than 80 percent of applicants were Roma (European Commission, 2013).

\subsection{Macedonia's Response to EU Requests}

According to official information from the Ministry of Internal Affairs of the Republic of Macedonia from 2011, enhanced measures and activities to prevent the large number of persons seeking asylum in Member States have started to be enforced. In the specific case of the Republic of Macedonia, Roma people's right to freedom of movement has been seriously jeopardized as soon as the visa liberalization entered in effect. Statistical data on the number of asylum seekers under the visa-free regime have played a major role in policy-making and political debates centred on measures for prevention of ungrounded asylum applications, besides the fact that the rate of admissible asylum applications by Macedonian citizens, according to official data from Eurostat is very small compared with that which applies to other countries in the Western Balkans (European Commission, 2013) (Eurostat, 2014). Analysis of the method applied for rejecting ungrounded asylum applications and for returning asylum seekers reveals interesting variations among the Schengen Area Member-States. In the first three months of 2013, Germany returned practically all asylum seekers from the Western Balkans through forced return procedures; Luxembourg proceeded 
almost entirely via the voluntary return track; Sweden and Belgium used mainly the voluntary track; while Switzerland used the two methods in almost equal measure (European Commission, 2013). In the prevention of Roma to cross the Macedonian state borders, Republic of Macedonia's role in the resolution of this problem should have been both direct and meaningful. The Constitution of the Republic of Macedonia guarantees equality and freedom of movement for all citizens, while the international treaties to which the Republic of Macedonia is a signatory state prohibit all types of discrimination and restriction of the freedom of movement. On the other hand, it should be noted that the European Commission's Visa Liberalization Roadmap clearly indicates that the Republic of Macedonia should guarantee its citizens freedom of movement, which should not be burdened with unjustified restrictions and discriminatory practices, and that the Republic of Macedonia should duly investigate all cases of ethnically motivated incidents caused by police officers in regard to freedom of movement, including practices targeting members of minority communities in Macedonia. Since 2011, Roma were frequently stopped at border crossings and denied exit without any real arguments and proof of lack of documentation. Questions were raised whether the measures taken by border authorities in the Republic of Macedonia perceive the citizens of the Republic of Macedonia as potential danger to the public order, legal order and the state's security, or as potential danger to the state's distorted international image and its relations with the EU and its Member-States. The institutions were being wisely silent, but also that the members of Roma community in the Republic of Macedonia feared to openly speak about this problem, for a long time. Law suits began to fill the courts by the end of 2014 with the assistance of the Macedonian Young Layers Association (MYLA) and their project of free aid. MYLA, received the very first judgment laying down discrimination and violation of equality in which the Ministry of Interior (MOI) appears as a defendant because it prevented the plaintiff, a person belonging to the Roma nationality, to leave the territory acting contrary to the Law on border control and restrict his right to free movement and the right to equality (MYLA, 2016/1). Within this project, MYLA had also unsuccessful judgements which prove the constant attempt of the Macedonian courts to neglect the right of free movements of persons and the prohibition against discrimination (MYLA, 2016/2).

\section{Macedonia's Experience with Refugee Crisis}

\subsection{Large Influx of Migrants' Passing Through'}

Republic of Macedonia faced significant and moreover increased number of asylum seekers coming from countries outside the Balkans and Europe after the Bosnian crisis and the Kosovo war. In 2008, there were 50 lodged asylum applications, following by increases in the numbers in 2009- 90, then 2010 with 180 asylum applications. According the UNHCR official statistical data in 2011, 740 asylum applications (UNHCR, 2011, p.27) were submitted in front of the Section for asylum at the Ministry of Interior as a first instance authority. Vast majority of these applications were submitted by applicants coming from the world's most vulnerable countries such as Afghanistan (427 applications), Pakistan (172) and Somalia (53) asylum applications. This means that the annual change 2010- 2011 is 311 per cent. 
In 2015 the biggest number of refugees and migrants who entered the Europe was registered, reaching one million before the end of December. It was an outstanding period in the history of migration movements. In the middle of the so-called largest refugee crisis in the world, EU and EU Member States have been under huge pressure to solve and to tackle the challenges of the major influx coming from the southern European borders. While Hungary immediately closed the borders and Austria announced a similar action if the situation escalates (The Guardian, 2015), Western Balkan countries were under huge pressure. Refugees travelling from Turkey through Greece arrived at the Macedonian southern borders. Relations between states within the EU and outside have been tested greatly while attempting to either blame the neighbor for poor management of refugees or by arguing on the distribution of quotas to equally share the burden. The EU has admitted in the European Agenda on Migration (released in May, 2015), that emergency measures are necessary because the collective European policy on the matter has fallen short (European Commission, 2015). One of the key measures underlined in the agenda was to respond to high-volumes of arrivals within the EU by relocation or in other words "Member States will need to show solidarity and redouble their efforts to assist those countries on the frontline" (European Commission, 2015, p.4). In order to do so, the Commission proposed setting up a new 'hotspot' approach, where European Asylum Support Office, Frontex and Europol will work on the ground with frontline Member States to swiftly identify, register and fingerprint incoming migrants. The Commission, furthermore, proposed a redistribution key based on criteria such as GDP, size of population, unemployment rate and past numbers of asylum seekers and of resettled refugees.

\subsection{Facing the Challenge of Hosting Migrants}

Meanwhile, waiting for all these proposals to be set in practice and put operational, Macedonia along with other Western Balkan countries were facing the challenge of hosting and managing refugees coming from Greece. These countries formed one of the main migration routes (so-called Balkan route) to countries of the European Union. During one year, the number of newly arrived asylum seekers who entered in Macedonia as part of increased movement of people in mixed migratory movements dramatically increased. Asylum seekers and migrants passed through the region of Asia, Africa and the Middle East en route to Western Europe. With the continuation of the conflict in Syria, the majority refugees who arrived in the Western Europe countries were coming from Syria. Most of them arrived from Turkey to Greece by sea, and continued their way to Germany, Sweden or Denmark. In early June 2015, the number of migrants and asylum seekers who arrived on the southern border with Greece varied between 300-500 persons daily. With the deepening of the crisis, a growing number of Refugees began arriving in Macedonia, average daily basis grew over the months, reaching only 11,072 registered on 9 November 2015 at the transit center in Vinojug Gevgelija. Majority of asylum seekers perceive Macedonia as a transit-country rather than as a country of final destination. This led to practice of state institutions to work more on facilitating transit, rather than improving national Asylum System.

An indicator for calculating the number of people crossing Macedonia is the number of 
intentions to request asylum. Amendments of the Law on asylum and temporary protection in 2015, have introduced the category of 'intention to request asylum' (Law on Asylum and Temporary Protection 101/15) and consequently, the Ministry of Interior reported regularly the number of issued intentions to request asylum until mid-March 2016. Since 19th of June until 31st of November 2015, 384481 intentions were issued to foreign nationals, whereas since that date, there were only 86 asylum requests, based on the previously issued intention (Ministry of Interior of the Republic of Macedonia, 2015a). For 2016 the Ministry reported only until mid-March. According to the Ministry, in the period between 1st of January 2016 and 20th of March 2016, 89623 foreigners obtained the intentions to request asylum, whereas for the same period 29 foreigners (from Syria and Afghanistan) requested asylum in Republic of Macedonia (Ministry of Interior of the Republic of Macedonia, 2016).

\subsection{Declaring Emergency Situation and Subsequent Developments}

Macedonia declared emergency situation on 19 August 2015, in the southern and norther border crossings. The Ministry of Interior at that time declared, that the Macedonian army could be involved in securing the borders. To act upon the decision of the government main headquarter at the Center for Crisis Management was formed with a responsibility to prepare an action plan. The Ministry publicly announced that the increased control of the southern border is not a final solution to the problem and that it is expected that soon a unique, humane response by the EU will established, which will cover all of the countries most affected by the migrant crisis and jointly will share the burden of confronting the specific challenges (Ministry of Interior of Republic of Macedonia, 2015b). In the upcoming months uncertainties were present in reference to whether the borders will be closed or not. Since it was a situation where clearly there is a chained action, the possibility of closing Macedonian borders were depended on whether its northern neighbor Serbia will close its borders as well. This was due to the low capacity of the country to deal and host huge number of refugees and migrants on its territory.

The refugee crisis was filled with accusations of failures which have spread the news, and Macedonia was among them. The Macedonia's President has told Germany "your country has completely failed" in its security response to the refugee crisis. He pointed out in a public interview that Macedonia, which is not a European Union Member State, have seized 9,000 forged or stolen passports from refugees (Bild, 2016). While the discourse on refugees have been mixed with the discourse of potential terroristic attacks, as Mr. Ivanov pointed out, Macedonian offers to share intelligence and data on alleged jihadists have been rejected by Europe. The wide open accusations by the Macedonian president towards EU refugee management, has come right after Macedonia fully closed the border with Greece (in March, 2016). Macedonia has faced with a fact, to protect EU borders as a non-EU Schengen state. Conversely, Macedonia was accused to use the migration crisis to override its democratic commitments (Herczog, 2016). Greece accused Macedonia of "shaming" Europe by using plastic bullets, stun grenades and tear gas to beat back refugees from the border fence between Macedonia and Greece (Squires, 2016). Media was accusing Macedonia of using tear gas on migrants while Italy rescues 4000 in the Mediterranean (Charlton, 2016). 
With no real policy for refugees' management and action for overcoming the crisis, EU's only hope was to accord with Turkey. In the European meeting in March, 2016, the proposed agreement was for the EU to return migrants (to alleviate the situation in Greece) who do not qualify for refugee status to Turkey, in return for resettling within Europe an equal number of refugees. Then again, Turkey demanded more financial means and faster visa-free travel, in return (Euronews, 2016a). The agreement includes a commitment for the EU to cooperate with Turkey in endeavors to establish so-called "safe areas" inside Syria. In broader perspective, this EU breaking deal was criticized as act of contradiction of EU principles guaranteeing the right to seek asylum and against collective expulsion (Human Rights Watch, 2016). However, this has not stopped refugees from seeking shelter in EU countries. The International Organization for Migration (IOM) reported that as of 21 September 2016, a total of 317,228 migrants and refugees have arrived in Europe by land and sea routes since the start of 2016 (IOM, 2016a). In Macedonia numbers have decreased. The number of migrants and refugees remaining at the reception centre in Gevgelija (southern border) was 131, and in Tabanovce (northern border) approximately 81 (IOM, 2016b).

When discussing Macedonian efforts to cooperate with neighboring countries and other EU countries in managing the refugee crisis, it must be noted that numerous actions and efforts were taking place. In 2015, Macedonia, Serbia, Hungary and Austria have signed a Memorandum for dealing with the refugee crisis, admitting it as small but significant steps towards managing the encountered problems and challenges (Government of the Republic of Macedonia, 2015). The Vienna summit (with a participation of 11 countries, along with EU representatives) in September 2016, has decide on sealing off of the so-called Balkan route, and a plan of conclusion of repatriation agreements with North African states, Afghanistan and Pakistan. Euronews correspondent Gábor Tanács reported from Vienna that "countries along the Balkan route have a habit of bickering - but also of cooperating. The question is which habit will prevail as they try to handle the migrant crisis" (Euronews, 2016b). Macedonia has also participated in the summit along with the other countries from the Balkan route. After a long time of hesitation, it has been decided a decisive role of Frontex outside of the EU (EU, 2016). The border agency will have a more comprehensive border surveillance and refugee deterrence authority with a first deployment will take place within the EU, in Greece on the borders with Macedonia and Albania.

\section{Macedonian Legal Framework and Its Alignment with the EU Acquis in the Field of Migration and Asylum}

The Stabilization and Association Process (SAP) are a foundation on which the countries of the Western Balkans and the European Union cooperate on policies related to migration and asylum. The contractual relationship between Macedonia and the EC was initiated in 2001 with the signing of the Agreement. In regards to migration, the emphasis in the Agreement was placed on prevention and control of irregular migration as well as readmission of nationals of other countries and stateless persons; in addition, the consultation and cooperation efforts were concentrated on assistance in drafting the necessary legislation, best practices of controlling and protecting the borders, as well as enhancing the efficiency of the institutions charged with fighting and preventing crime and combating trafficking in human 
beings. The cooperation between Macedonia and the EC in the area of asylum, was propelled towards development and implementation of national legislation in order to meet the standards of the 1951 Geneva Convention (Council of the EU, 2001). Furthermore, the Visa liberalization dialogue between the EC and Macedonia contributed immensely on further alignment with the EU acquis in the area of migration.

\subsection{Law on Asylum and Temporary Protection}

The pursuit for membership in the EU results in adopting and implementing the Union's asylum acquis and as such had (and still has) a significant impact on the refugee protection regime in the Republic of Macedonia. The accession processes however encouraged significant advances in the refugee protection in the country, thus initiating new amendments and improvements in the Law on Asylum and Temporary Protection (LATP). In May, 2007 in the light of the need to harmonize LATP with the 2004 Qualification Directive, first amendments introduced subsidiary protection and defined a person under subsidiary protection; further introducing four more cessation clauses (death, acquisition of citizenship, acquisition of residence permit and voluntary departure from the territory of the Republic of Macedonia), which were fortunately erased by the 2009 Amendments of LATP. In October, 2008 passed another Law amending the LATP - the term 'person under humanitarian protection' was replaced with the term 'person under subsidiary protection', following by changes made in the applicant's right to use appropriate remedy - namely the possibility of an administrative dispute against the decisions of the first instance authority in front of competent court. December, 2009 third amendments of LATP most importantly introduced: Article 9-a „First country of asylum” based on Article 26.1 of the Procedures Directive; Article 24.2 of the Qualification Directive envisages that residence permit for persons under subsidiary protection must be valid for at least one year and this provision was incorporated in Article 58 of LATP; deleted the fourth paragraph of Article 32 LATP and amended Article 35 (Smilevska, 2012). As stated before, LATP, has been amended in 2015 introducing the term 'intention to request asylum' and in 2016 another amendment introduced the category 'third safe country' (Law on Asylum and Temporary Protection, 71/2016)

\subsection{Towards EU Acquis Alignment}

On a policy level, in 2009, the Assembly adopted a 5-year strategic policy document indicating the state of affairs, problems and measures regarding migration management, including irregular migration. The Resolution on Migration Policy 2009-2014 consequently determines the principles, elements, criteria and presumptions of the migration policy, as well as the migration processes and return policy in Macedonia (Resolution on Migration Policy of Macedonia 2009-2014). Republic of Macedonia is implementing the National Strategy for combating trafficking in human beings and illegal migration 2013-2016 in order to comply with the EU directive 2011/36/EU which sets out minimum standards in preventing and combating trafficking in human beings and protecting victims.

The alignment with the EU acquis has been a slow process for Macedonia showing some successful results. Macedonia has shown its commitment in applying comprehensive legal framework in the area of irregular migration legislation, and taking concrete step in fully 
transposing the directives in national legislation. Besides the country's evidenced progress towards overall compliance, still, Macedonia is partially compatible with the EU acquis in the area of irregular migration (Andeva \& Necev, 2016).

The Dublin System is the cornerstone of the Common European Asylum System. It is constituted by the Dublin and Eurodac Regulation, and their implementing provisions. It standardizes the criteria and mechanisms for determining Member States' responsibility for examining an asylum application and establishes a EU asylum fingerprint database. When discussing the Macedonia's alignment in this specific field, it is important to underline that the implementation of the Dublin system requires full membership in the EU, therefore, is only applicable once Macedonia becomes a MS. Therefore, the accession process greatly serves as preparatory period for full harmonization with these Regulations.

Regardless of the above mentioned, few important remarks for the Macedonian asylum framework can be highlighted. The necessary legal framework for establishment of a national database for foreigners, covering data on asylum, migration and visas was provided by the Law on foreigners in 2010. Also the LATP and accompanying subordinate legislation are the main source to be taken into consideration when assessing the level of compliance with the EU asylum acquis. The LATP contained an entire chapter devoted to temporary protection of persons in the event of mass influx. In such events, according to Art. 62, the Government of Macedonia may grant temporary protection to persons coming directly from a state where their life, safety or freedom have been threatened by war, civil war, occupation, internal conflict linked with violence or mass violation of human rights. This is off course, in line with the 1951 Geneva Convention relating to the status of refugees (to which Macedonia is a signatory party), nonetheless furthermore proves that Macedonia has taken into consideration such measures and from a legal point of view, contains provisions which establish and covers mass influx events. Temporary protection right is also covered by the law. Taking in consideration the frequent changes and revision of the asylum acquis on EU level; the Macedonian legislation is to a great extent complied with EU standards and regulation primarily in the policy areas of common procedures for granting international protection, determining refugee status, temporary protection and reception conditions (Andeva \& Necev, 2015). Other policy and measures related to common databases and sharing responsibility burden are only applicable for discussion once Macedonia joins the EU family.

\section{Concluding Remarks}

This article attempted to present the key milestones of Macedonian challenges and experience with migration. It presented three main challenges, this country faced through the years, in the field of migration and free movement of persons. Macedonia was challenged to seek measures and extracurricular solutions in dealing with the prevention of asylum application in the EU, from its own citizens, by clearly not respecting the right and discriminating citizens on the basis of race. Such an act has been largely triggered by the measures and actions made by the EU Member States. The EU and its Member-States, could have disposed with mechanisms that could prevent the occurrence of so-called "false asylum seekers", without having to transfer the responsibility to the Western Balkans by issuing recommendations and 
imposing terms and conditions that they need to fulfil. Instead, Western Balkans, especially Macedonia has faced a burden and challenge to limit free movement of its own citizens. Nevertheless, these conclusions exclusively concern relations between the EU and the Western Balkans.

The significant increase of migrants transiting Macedonia in addition to the migrant crisis in which numbers and politics have constantly been altered, has been the main cause of many concerns among EU MSs and Western Balkan countries in the past two years. This complex state of play posed a threat for effective implementation and operationalization of policies especially in events of mass influx of migrants. Especially for transit countries as Macedonia, which is in a process of transposing the acquis communautaire in the area of irregular migration and asylum as part of Chapter 24 of the accession negotiations. Ineffectiveness in the implementation of the relevant acquis was evident in recent times when the Macedonian authorities had to seek extracurricular solutions for dealing with the increased migrant flow outside the existing community legislation. The path of refugees and migrants' management in Macedonia has not been laidback. Macedonian citizens have showed great hospitality and charity; numerous voluntary organizations assisted by funds from the UNHCR and other governmental institutions have tried to minimize the impact of the large number of migrants on its territory. The Center for Crisis Management has also played a significant role in the in-field operations.

The increased flow of migrants coming to Europe and passing through Republic of Macedonia has filled the daily news with many debates and discussions, which go often in different directions and create misunderstandings and misinterpretations concerning the situation at hand. Macedonia joined the crises discourse since the middle of August 2015, with increased influx of migrants on its territory. Such a significant number has considerably influenced Macedonian society perception, feelings and reactions to migration as phenomenon, and the actions which consequently come along. Society was not immune to witnessing prejudices, fears and various placed information and facts as a result of such developments (Najcevska, 2015), however it has managed to stay calm despite the external and internal political factors in place. Macedonia continued to put effort on aligning its legislation with the EU acquis, limited to its financial and operational capacities.

\section{References}

Andeva, M., \& Necev, Z. (2016). Macedonia's compliance with EU policies and regulations for irregular migration and asylum. Conference Proceedings "Challenges of contemporary society". Institute for Sociological, Political and Juridical Research: Skopje.

Bild. (2016). Macedonian president settles a score here, Bild. Retrieved November 1, 2016, from

http://www.bild.de/politik/ausland/gjorge-ivanov/macedonian-president-settles-a-score-here44888176.bild.html

Charlton, C. (2016). Europe's refugee crisis rumbles on: Macedonia uses tear gas on migrants trying to pull down border fence while Italy rescues 4,000 in the Mediterranean in the past 
two days - sparking fears of 'alarming' rise in illegal sea crossings, Dailymail. Retrieved September 2 , 2016 , from http:/www.dailymail.co.uk/news/article-3537705/Europe-s-refugee-crisis-rumbles-Macedoni a-uses-tear-gas-migrants-trying-pull-border-fence-Italy-rescues-4-000-Mediterranean-past-tw o-days-sparking-fears-alarming-rise-illegal-sea-crossings.html\#ixzz4PnirDBcg

Council of Europe. (2013). Report by Nils Muižnieks, Council of Europe Commissioner for Human Rights, following his visit to the "former Yugoslav Republic of Macedonia", from 26 to 29 November 2012), CommDH(2013)4.

Council of the European Union. (2009). Visa liberalisation for Western Balkan countries, Brussels, 30 November 2009 (16640/09 (Presse 349)). Retrieved from http://www.consilium.europa.eu/uedocs/cms_data/docs/pressdata/en/jha/111561.pdf.

EU (2016) Regulation (EU) 2016/1624 of the European Parliament and of the Council of 14 September 2016 on the European Border and Coast Guard and amending Regulation (EU) 2016/399 of the European Parliament and of the Council and repealing Regulation (EC) No $863 / 2007$ of the European Parliament and of the Council, Council Regulation (EC) No 2007/2004 and Council Decision 2005/267/EC, Official Journal of the European Union, 16.9.2016.

Euronews. (2016a). EU leaders claim 'breakthrough' at migration summit but details need more work, Euronews. Retrieved November 12, 2016, from http://www.euronews.com/2016/03/08/eu-leaders-claim-breakthrough-at-migration-summit-b ut-details-need-more-work

Euronews. (2016b). 'Balkan route' leaders meet in Vienna to tackle migration crisis, Euronews. $\quad$ Retrieved November $12, \quad 2016$, from http://www.euronews.com/2016/09/24/balkan-route-leaders-meet-in-vienna-to-tackle-migrati on-crisis

European Commission (2013) Free movement: Vice-President Reding's intervention at the December Justice and Home Affairs Council. Retrieved November 12, 2016, from http://europa.eu/rapid/press-release_SPEECH-13-1025_en.htm

European Commission (2013a) Report from the Commission to the European Parliament and the Council, Fourth Report on the Post-Visa Liberalisation Monitoring for the Western Balkan Countries in accordance with the Commission Statement of 8 November 2010, Brussels, 28.11.2013, COM(2013) 836 final

European Commission (2015) Communication from the Commission to the European Parliament, the Council, the European Economic and Social Committee and the Committee of the regions, A European Agenda on Migration, COM(2015) 240 final, Brussels, 13.5.2015.

European Parliament (2013) Parliament backs rules allowing suspension of visa-free travel only as a last resort, Press release, 12.9.2013. Retrieved September 3, 2016, from http://www.europarl.europa.eu/news/en/news-room/20130910IPR19556/ep-backs-rules-allow ing-suspension-of-visa-free-travel-only-as-a-last-resort 


\section{Macrothink}

International Journal of Social Science Research

ISSN 2327-5510

2017, Vol. 5, No. 2

Eurostat. (2014). Asylum applicants and first instance decisions on asylum applications: 2013 - Issue number 3/2014.

Government of the Republic of Macedonia. (2015). Macedonia, Serbia, Austria and Hungary signed Memorandum for dealing with the refugee crisis, Press release. Retrieved September 2, 2016, from http://vlada.mk/node/11065

Herczog, E. (2016) Europe can't afford to be blackmailed by Macedonia, Politico. Retrieved November 10, 2016, from http://www.politico.eu/article/europe-blackmailed-macedonia-refugee-crisis-balkan-route-gre ece/

Human Rights Watch (2016) EU/Turkey: Mass, Fast-Track Returns Threaten Rights. Retrieved September 15, 2016, from https://www.hrw.org/news/2016/03/08/eu/ turkey-mass-fast-track-returns-threaten-rights

IOM. (2011). Glossary on Migration, International Migration Law Series No 25.

IOM. (2016a). Situation Report, 22 September 2016.

IOM. (2016b). Situation Report, 11 August 2016.

Law on amending the law on asylum and temporary protection, Official Gazette of the Republic of Macedonia, no. 101 from 18.06.2015.

Law on amending the law on asylum and temporary protection, Official Gazette of the Republic of Macedonia, no. 71 from 11.04.2016.

Law on amending the law on foreigners, Official Gazette of the Republic of Macedonia, no. 156 from 6.12.2010.

Ministry of Interior of the Republic of Macedonia. (2015a). Press release, 31.12.2015. Retrieved October 1, 2016, from http://www.mvr.gov.mk/vest/1193

Ministry of Interior of the Republic of Macedonia. (2016). Press release, 21.03.2016. Retrieved October 1, 2016, from http://www.mvr.gov.mk/vest/1648

Ministry of Interior of the Republic of Macedonia. (2015b). Засилено обезбедување на јужната и северна граница [Enforced security on the south and north state border], Press release, 20.08.2015. Retrieved September 1, 2016, from http://www.mvr.gov.mk/vest/299

MYLA. (2016/1). Донесена позитивна пресуда за повреда на право на еднаквост и повреда на слобода на движење [Decision on violation of the right to equality and a violation of freedom of movement]. Retrieved August 31, 2016, from http://myla.org.mk/донесена-позитивна-пресуда-за-повред/

MYLA. (2016/2). 'Студија на случај: X.X против Министерството за внатрешни работи на PM' [Case study: H.H against Ministry of Interior of the Republic of Macedonia]. Retrieved October 1, 2016, from http://myla.org.mk/x-X-

Najcevska, M. (2015). Бегалци, мигранти и ксенофобија во македонските медиуми 


\section{Macrothink}

International Journal of Social Science Research

ISSN 2327-5510

2017, Vol. 5, No. 2

[Refugees, migrants and xenophobia in the Macedonian media]. Retrieved November 12, 2016, from http://nemrazi.mk/begaltsi-migranti-i-ksenofobija-vo-makedonskite-mediumi/

Romea (2014) Vivian Reding: The Real Problem of Free Movement Are the Roma, Speech. $\begin{array}{llll}\text { Retrieved November } & 12, & \text { 2016, from }\end{array}$ http://www.romea.cz/en/news/world/viviane-reding-the-real-problem-of-free-movement-are-t he-roma

Smilevska, M. (2012). 'Trends in asylum-seeking in light of Macedonia's accession processes in the European Union'. EU Policy Brief. Skopje: Konrad Adenauer Stiftung.

Squires, N. (2016) Refugee crisis: Greek PM accuses Macedonia of 'shaming' Europe, Telegraph.uk. Retrieved November 5, 2016, from http://www.telegraph.co.uk/news/2016/04/11/greek-officials-condemn-macedonians-for-useof-force-after-300-r/

The Guardian (2015) Austria plans to close border as refugee crisis grows, The Guardian. Retrieved September 5, 2016, from https://www.theguardian.com/world/2015/sep/06/austria-close-border-refugee-crisis-europemunich-migrants

UNHCR. (2011). Asylum Levels and Trends in Industrialized Countries Statistical overview of asylum applications lodged in Europe and selected non-European countries. Retrieved November 10, 2016, from http://www.unhcr.org/statistics/unhcrstats/4e9beaa19/asylum-levels-trends-industrialized-cou ntries-2011-statistical-overview.html

\section{Copyright Disclaimer}

Copyright for this article is retained by the author(s), with first publication rights granted to the journal.

This is an open-access article distributed under the terms and conditions of the Creative Commons Attribution license (http://creativecommons.org/licenses/by/3.0/). 